\title{
ANALISIS REGRESI DAN KORELASI KANDUNGAN GULA JAGUNG MANIS PADA BERBAGAI VARIETAS DAN WAKTU PANEN
}

\author{
Kiky Mariani $^{1}$ ), St. Subaedah ${ }^{2)}$, Edy Nuhung ${ }^{2)}$ \\ ${ }^{1)}$ Mahasiswa Magister Agroekoteknologi PPs-UMI, Makassar \\ 2) Jurusan Agroteknologi Fakultas Pertanian, UMI
}

\begin{abstract}
ABSTRAK
Pengembangan jagung manis di Sulawesi Selatan banyak diminati oleh petani karena kebutuhan konsumen akan jagung manis di pasaran makin meningkat, oleh karena itu komoditas ini perlu mendapat perhatian. Peningkatan produktivitas jagung manis terus diupayakan dengan perbaikan teknologi budidaya yang tepat, seperti misalnya pemilihan varietas. Pemilihan varietas jagung manis mempunyai peran besar tidak hanya upaya peningkatan produktivitas tetapi juga tingkat kualitas dari jagung manis itu sendiri yaitu rasa manisnya. Penelitian ini dilakukan dengan tujuan untuk menganalisis kandungan gula jagung manis dari berbagai varietas dan umur panen. Penelitian ini dirancang dengan rancangan Split Plot Design yang terdiri dari petak utama yaitu pengaruh varietas yang terdiri dari tiga jenis yaitu varietas Bonanza, Talenta dan Master Sweet. Sebagai anak petak adalah perlakuan waktu panen yang terdiri dari waktu panen 65, 70 dan 75 hari setelah tanam. Dari kedua faktor diperoleh 9 kombinasi perlakuan. Hasil penelitian menunjukkan bahwa varietas Bonanza dan Master Sweet menghasilkan kadar gula tertinggi. Pada perlakuan waktu panen menunjukkan bahwa kandungan gula tertinggi dijumpai pada saat panen 70 hari setelah tanam. Berdasarkan analisis regresi ditemukan bahwa terdapat hubungan yang signifikant antara varietas dan waktu panen terhadap kandungan gula biji jagung manis dengan nilai korelasi sebesar 0,68
\end{abstract}

Keywords : varietas, jagung manis, kandungan gula, umur panen

\section{PENDAHULUAN}

Jagung manis atau sweet corn merupakan komodistas pertanian yang sangat di gemari karena rasanya yang enak dan manis. Jagung manis di konsumsi dalam keadaan segar sebagai jagung rebus, campuran sayuran, sop, dijadikan bahan pembuat kue, yogourt dan sebagai makanan kaleng.

Salah satu kriteria kualitas jagung manis di tentukan oleh bobot tongkol segar dan kandungan gula. Semakin tinggi bobot tongkol dan kandungan gula semakin tinggi kualitasnya semakin baik.
Kandungan gula pada jagung manis akan sangat menentukan kualitasnya. kualitas hasil diukur dalam bentuk kandungan gula. Semakin tinggi kandungan gula maka kualitasnya semakin baik. Sukrosa dan gula reduksi (glukosa dan fruktosa) hasil fotosintesis yang ditransfer ke berbagai organ pengguna yang kemudian sebagian digunakan untuk pemeliharaan integritas organ tersebut, sebagian lagi dikonversi ke bahan struktur tanaman dan sisanya sebagai cadangan makanan (Hartini, 1993; Gardner, et al., 2010). Menurut 
Palungkun (1995) dalam Surtinah (2008) kandungan gula jagung manis cukup tinggi yaitu $5-6 \%$, sehingga rasanya manis dari jagung biasa, namun ada juga varietas lokal yang memiliki kadar gula 9 - $11 \%$, sedangkan varietas Hybrid Super Sweet Corn memiliki kadar gula 16 - 18 $\%$ (Siswono, 2004).

Produksi dan kandungan gula dari jagung manis banyak dipengaruhi oleh varietas yang digunakan (Saleem, 2003: Andersen, 2018). Pemilihan varietas yang akan ditanam oleh petani harus mempertimbangkan aspek tanah dan iklim, minat petani, potensial hasil tinggi, tahan penyakit dan kekeringan serta berumur genjah (Azrai, 2013). Pemilihan varietas jagung manis mempunyai peran besar tidak hanya upaya peningkatan produktivitas tetapi juga tingkat kualitas dari jagung manis itu sendiri yaitu rasa manis pada jagung manis.

Umumnya umur panen jagung manis adalah 70-85 hari setelah tanam di dataran menengah dan 60-70 hari setelah tanam di dataran rendah. Jagung manis umumnya dikonsumsi dalam keadaan segar sehingga harus tersedia dalam keadaan segar setiap saat dan tidak dapat disimpan dalam waktu relatif lama
(Syukur dan Rifianto, 2014). Komposisi kimia yang ada pada jagung bervariasi tergantung umur dan varietasnya. Jagung manis mengandung vitamin $\mathrm{A}, \mathrm{B}, \mathrm{C}, \mathrm{E}$, mineral dan berkarbohidrat. Karbohidrat pada jagung manis mengandung gula pereduksi (glukosa dan fruktosa), sukrosa, polisakarida dan pati (Iskandar, 2006). Surtinah (2012) melaporkan bahwa jagung manis yang dipanen pada umur lebih dari 75 hari menghasilkan biji dengan tekstur yang lebih keras dan biji berkerut sehingga menurunkan kualitas produksi.

Umumnya umur panen jagung manis adalah 70-85 hari setelah tanam di dataran menengah dan 60-70 hari setelah tanam di dataran rendah. Menurut Rukmana (1997) umur panen jagung manis sanngat pendek yaitu $60-70$ hari setelah tanam hal ini membuat petani tergiur untuk melakukan usaha tani jagung manis karena dianggap menguntungkan. Umur panen sangat berpengaruh terhadap persentase bagian yang dapat dimakan (edible portion). Mutu jagung manis yang dipanen terlalu awal bijinya lebih kecil, sehingga bagian yang dapat dimakan lebih rendah. Sedangkan jagung yang panen terlambat akan berkurang kemanisannya 
dan biji jagung teksturnya menjadi lebih keras (Purwono dan Wahyuni, 1988).

Kualitas jagung manis ditentukan oleh adanya kandungan gula yang dikandung oleh biji jagung manis. Pemanenan yang tepat akan mempengaruhi kualitas jagung manis, karena apabila panen terlambat menyebakan biji jagung manis menjadi keriput, hal tersebut disebabkan oleh perubahan gula menjadi pati, sehingga diperlukan umur panen yang tepat pada varietas tertentu untuk mendapatkan biji jagung manis yang berkualitas.

Penelitian ini dilakukan dengan tujuan untuk menganalisis korelasi antara varietas dan waktu panen terhadap kandungan gula biji jagung manis.

\section{BAHAN DAN METODE}

Penelitian ini dilaksanakan di Kecamatan Bajeng Kabupaten Gowa, Provensi Sulawesi Selatan, yang berlangsung dari bulan April sampai Agustus 2018.

Adapun bahan dan alat yang digunakan dalam penelitian ini adalah : pupuk Urea, SP-36, $\mathrm{KCl}$, benih jagung manis Varietas Bonanza, Varietas Talenta, Varietas Master Sweet, insektisida, fungisida, pupuk organik cair, cangkul, tugal, sabit, timbangan digital, Hand refraktometer, mistar geser dan lain-lain.

Penelitian ini dirancang dengan rancangan split plot design yang terdiri dari petak utama dan anak petak. Sebagai petak utama adalah varietas yaitu:

$\mathrm{V} 1=$ Varietas Bonanza

$\mathrm{V} 2=$ Varietas Talenta

V3 $=$ Varietas Master sweet

Sebagai anak petak adalah waktu panen yang terdiri dari:.

$\mathrm{U} 2=$ umur panen $65 \mathrm{HST}$

$\mathrm{U} 3$ = umur panen $70 \mathrm{HST}$

$\mathrm{U} 4=$ umur panen $75 \mathrm{HST}$

Dari kedua faktor tersebut diperoleh 9 kombinasi perlakuan. Setiap kombinasi perlakuan diulang sebanyak tiga kali sehingga diperoleh 27 unit percobaan.

Persiapan lahan dimulai dengan melakukan pengolahan tanah, sehingga tanah menjadi gembur, rata dan bersih dari sisa-sisa gulma dan perakaran. Lahan yang sudah diolah, kemudian dibagi menjadi tiga blok sebagai ulangan. Jarak antara setiap blok $1 \mathrm{~m}$. Setiap blok dibagi menjadi tiga petak utama yang 7,5 $\mathrm{m} \mathrm{x} 3$ $\mathrm{m}$ (jarak antara setiap petak utama $1 \mathrm{~m}$ ). Setiap petak utama dibagi menjadi tiga 
anak petak yang berukuran 2,5 m x $3 \mathrm{~m}$. yang diamati adalah kadar gula jagung Penanaman dilakukan dengan menugal manis.

sedalam kurang lebih $3 \mathrm{~cm}$ dengan jarak tanam $70 \times 25 \mathrm{~cm}$. Penjarangan dilakukan saat tanaman berumur 2 MST dengan menyisakan satu tanam untuk setiap lubang tanaman. Pemupukan dilakukan untuk menunjang pertumbuhan tanaman dengan pupuk urea $350 \mathrm{~kg} / \mathrm{ha}$, SP-36 150 $\mathrm{kg} / \mathrm{ha}$ dan $\mathrm{KCl}(150 \mathrm{~kg} / \mathrm{ha})$. Penyiraman dilakukan secara rutin selama fase pertumbuhan tanaman. Pengendalian gulma dilakukan pada umur 21 hari dan 40 hari setelah tanam. Pemanenan dilakukan sesuai dengan ketentuan perlakuan yaitu pada umur 65,70 dan 75 hari setelah tanam. Adapun parameter
Data hasil pangamatan kadar gula jagung manis dari berbagai varietas dan waktu panen dianalisis secara regresi dan korelasi.

\section{METODE PENELITIAN}

Hasil analisis regresi hubungan antara varietas dan waktu panen terhadap kadar gula jagung manis pada Tabel 1 menunjukkan tingkat signikinasi lebih kecil dari 0,05 yaitu sebesar 0,002. Hal ini berarti bahwa bahwa varietas dan waktu panen berpengaruh signifikan terhadap kadar gula jagung manis.

Tabel 1. Hasil analisis of varians pengaruh varietas dan waktu panen terhadap kadar gula jagung manis

ANOVA $^{\text {b }}$

\begin{tabular}{llrrrrr}
\hline Model & & Sum of Squares & df & Mean Square & F & Sig. \\
\hline \hline 1 & 50.771 & 3 & 16.924 & 6.551 & $.002^{\mathrm{a}}$ \\
\cline { 2 - 7 } & Regression & 59.415 & 23 & 2.583 & & \\
\cline { 2 - 6 } & Residual & 110.187 & 26 & & & \\
\hline \hline
\end{tabular}

a. Predictors: (Constant), X4, X3, X2

b. Dependent Variable: Y

Berasarkan hasil analisis regresi, hasil yang disajikan pada Tabel 2 . dimana varietas dan waktu anen Berdasarkan hasil analisis regresi tersebut merupakan variabel bebas dan kadar gula diperoleh persamaan sebagai berikut: sebagai varietas tidak bebas diperoleh 
$Y=23,96-2,03 X_{2}-0,37 X_{3}-1,32 X_{4}$

$\mathrm{R}=0,68 ; \mathrm{R}^{2}=0,46$

Dari persamaan tersebut menunjukkan bahwa kadar gula varietas Bonanza dengan waktu panen 65 hari sebesar $23,96{ }^{\circ}$ Brix. Pada varietas Talenta terjadi penurunan kadar gula sebesar $2,03^{\circ}$ Brix untuk setiap penundaan waktu panen sebesar satu unit (5 hari). Pada varietas Master Sweet menujukkan hal yang sama dimana penundaan waktu panen sebesar satu unit akan menurunkan kadar gula sebesar $0,37^{\circ}$ Brix. Varietas merupakan salah satu aspek yang perlu diperhatikan dalam usaha pengelolaan teknik budidaya tanaman. Pemilihan varietas memegang peranan penting dalam budidaya tanaman, karena untuk mencapai produktivitas yang tinggi sangat ditentukan oleh potensi genetiknya (Subaedah et al., 2018).

Pada perlakuan waktu panen (X4) menunjukkan bahwa bahwa penundaan waktu panen sebesar satu unit (5 hari) akan menurunkan kadar gula sebesar 1,32 ${ }^{\circ}$ Brix. Hal ini sesuai dengan hasil penelitian Surtinah (2008) yang memelaporkan bahwa varietas dan umur panen menentukan kadar gula biji. Selanjutnya dilaporkan bahwa umur panen 70 hari setelah tanam menunjukkan kadar gula biji jagung manis yang paling tinggi yaitu 15,78\% untuk varietas Sweet Boy.

Tabel 2. Hasil analisis Koefisien regresi dari berbagai varietas dan waktu panen tehadap kadar gula jagung manis.

\begin{tabular}{|c|c|c|c|c|c|c|c|c|c|}
\hline \multicolumn{10}{|c|}{ Coefficients $^{\mathrm{a}}$} \\
\hline \multirow{2}{*}{\multicolumn{2}{|c|}{ Model }} & \multirow{2}{*}{\multicolumn{2}{|c|}{$\begin{array}{c}\begin{array}{c}\text { Unstandardized } \\
\text { Coefficients }\end{array} \\
\text { B Std. Error }\end{array}$}} & \multirow{2}{*}{$\begin{array}{c}\begin{array}{c}\text { Standardized } \\
\text { Coefficients }\end{array} \\
\text { Beta }\end{array}$} & \multirow{3}{*}{$\frac{\mathrm{t}}{36.112}$} & \multirow[b]{2}{*}{ Sig. } & \multicolumn{3}{|c|}{ Correlations } \\
\hline & & & & & & & order & Partial & Part \\
\hline \multirow[t]{4}{*}{1} & (Constant) & 23.906 & .662 & & & .000 & & & \\
\hline & $\mathrm{X} 2$ & -2.033 & .758 & -.474 & -2.684 & .013 & -.432 & -.488 & -.411 \\
\hline & $\mathrm{X} 3$ & -.367 & .758 & -.086 & -.484 & .633 & .152 & -.100 & -.074 \\
\hline & $\mathrm{X} 4$ & -1.317 & .389 & -.519 & -3.387 & .003 & -.519 & -.577 & -.519 \\
\hline
\end{tabular}

a. Dependent Variable: Y 
Dari hasil analisis korelasi diperoleh pada Tabel 3 menunjukkan nilai koefisien korelasi (R) sebesar 0,68. Hal ini berarti bahwa hubungan antara varietas dan waktu panen terhadap kadar gula cukup kuat. Sementara hasil analisis koefisien determinasi $\left(\mathrm{R}^{2}\right)$ diperoleh nila sebesar 0,46 yang berarti bahwa kadar gula jagung manis dipengaruhi oleh varietas dan waktu panen sebesar $46 \%$.

Hasil analisis korelasi menunjukkan bawa nilai korelasi $(\mathrm{R})$ sebesar 0,68 , hal ini berarti bahwa korelasi antara varietas dan waktu panen cukup kuat. Syukur dan Rifanto (2014) mengemukakan bahwa umumnya umur panen jagung manis adalah 75-85 hari setelah tanam di dataran menengah dan 60 sampai 70 hari setelah

Tabel 3. Hasil analisis koefisien korelasi dan koefisien determinasi dari berbagai varietas dan waktu panen tehadap kadar gula jagung manis.

Model Summary ${ }^{\text {b }}$

\begin{tabular}{llllrl}
\multicolumn{5}{c}{ Model Summary $^{\mathbf{b}}$} \\
\hline \hline & & & & \\
Model & $\mathrm{R}$ & R Square & Adjusted R Square & Std. Error of the Estimate \\
\hline \hline 1 & $.679^{\mathrm{a}}$ & .461 & .390 & 1.60726 \\
\hline \hline
\end{tabular}

tanam di dataran rendah. Kemudian menurut Iskandar (2006) komposisi kimia yang ada pada jagung manis bervariasi tergantung pada umur panen dan varietasnya. Hal ini yang menyebabkan terjadinya perbedaan kadar gula jagung manis dari berbagai varietas dan waktu panen. Dari hasil analisis regresi juga menunjukkan bahwa penundaan waktu panen akan menurunkan kadar gula biji jagung manis. Hal ini disebabkan karena komposis kima yang ada dalam biji jagung manis dapat berubah sesuai dengan umur tanaman. Jagung manis mengandung vitamin $\mathrm{A}, \mathrm{B}, \mathrm{C}, \mathrm{E}$, mineral dan berkarbohidrat. Karbohidrat pada jagung manis mengandung gula pereduksi (glukosa dan fruktosa), sukrosa, polisakarida dan pati (Iskandar, 2006).
a. Predictors: (Constant), X4, X3, X2
b. Dependent Variable: Y 
Kadar gula jagung manis tertinggi dijumpai pada varietas Bonanza dan Master Sweet. Menurut Avivi (2005), proses sintesis gula pada tanaman dipengaruhi oleh dua faktor, yaitu faktor dalam dan faktor lingkungan. Faktor dalam meliputi genotipe yang digunakan, sedangkan faktor lingkungan meliputi suhu, ketersediaan cahaya, air, dan lain sebagainya. Nilai kandungan gula yang sangat tinggi pada jagung manis tersebut kemungkinan besar dipengaruhi oleh faktor gen pengendali rasa manis dalam bijiinya dan umur tanaman saat pengambilan sampel kandungan gula. Hal ini sesuai dengan karakteristik dari varietas yang digunakan yang masingmasing mempunyai kandungan gula tergolong tinggi. Hasil penelitin ini sesuai yang ditemukan oleh Dinda et al., (2015) yang menguji kadungan gula dua varietas yaitu jagung manis ungu dan jagung manis kuning dan menemukan adanya perbedaan kandungan gula dari kedua varietas tersebut, yang mana kandungan gula jagung manis ungu ternyata lebih tinggi $\left(25,16^{\circ} \mathrm{Brix}\right)$ dibandingkan dengan kandungan gula jagung manis kuning $\left(10,63^{\circ}\right.$ Brix $)$ dan kontrol $\left(11,38^{\circ}\right.$ Brix $)$. Derajat kemanisan jagung manis ungu termasuk dalam kategori sangat tinggi karena kandungan gulanya lebih dari $24^{\circ}$ Brix. Sementara itu kandungan gula jagung manis kuning tergolong sedang karena di bawah 18 ${ }^{\circ}$ Brix.

\section{KESIMPULAN}

Berdasarkan hasil analisis yang telah dilakukan maka ditarik kesimpulan sebagai berikut:

1. Kandungan gula tertinggi dijumpai pada Varietas Bonanza dan Master Sweet.

2. Waktu panen 65 hari menghasilkan kadar gula yang tertinggi untuk semua varietas yang diuji.

3. Terdapat hubungan yang signifikant antara varietas dan waktu panen terhadap kadar gula jagung manis dengan nilai korelasi 0,68. Semakin lawa waktu panen semakin menurun kadar gula untuk semua varietas yang diuji.

\section{DAFTAR PUSTAKA}

Andersen C.R. 2018. Home Gardening Series Sweet Corn. Agriculture and Natural Resources. University of Arkansas, United States Department of Agriculture, and County Governments Cooperatin. https://www.uaex.edu/publications/ PDF/FSA-6008.pdf. Accessed December 15, 2018

Avivi, S. 2005. Analisis variabilitas karakter fenotipe dan kadar gula tiga 
varietas jagung manis dan hibrida bisi 2. Jurnal Stigma, 8 (2): 193-198

Azrai, M. 2013. Jagung Hibrida Genjah: Prospek pengembangan menghadapi perubahan iklim. Iptek Tanaman Pangan 8(2):90-96.

Dinda Dewanti, P. Basunanda, A. Purwanto. 2015. Variabilitas karakter fenotipe dua populasi jagung manis (Zea mays L. Kelompok Saccharata). J. Vegetalika 4(4):35-47

Gardner. F.P. . R.B. Pearce and R.L. Mitchell. 2010. Physiology of Crop Plants. Scientific Publishers. 327p.

Hartini, N., 1993. Pengaruh Umur Panen dan Suhu Pendingin terhadap perubahan beberapa sifat Fisika Kimia Jagung Segar Selama Periode Penyimpanan. Waktu Panen yang Tepat Menentukan Kandungan Gula Biji Jagung Manis (Zea Mays saccharata). Staf Pengajar Fakultas Pertanian Universitas Lancang Kuning Jurusan Budidaya Pertanian. Vol 4, No. 2

Iskandar, D., 2007. Pengaruh Dosis Pupuk N, P, K, Terhadap Pertumbuhan dan Produksi Tanaman Jagung Manis di Lahan Kering. Balai Penelitian Pertanian dan Teknologi, Jurnal Saint dan Teknologi. pp.1-2

Palungkun R dan Asian 2004. Sweet Corn dan Baby Corn: Peluang Bisnis Pembudidayaan dan Penanganan Pasca Panen. Pengaruh Macam dan Cara Aplikasi Pupuk Organik
Terhadap Pertumbuhan dan Produksi Tanaman Jagung Manis (Zea mays saccharata, Sturt). Jurnal Produksi Tanaman 5(3):383-389

Purwanto, I.M., dan Wahyuni, S. 1988.

Teknik Budidaya Jagung Manis.

Waktu Panen yang Tepat

Menentukan Kandungan Gula Biji Jagung Manis (Zea Mays saccharata). Staf Pengajar Fakultas Pertanian Universitas Lancang Kuning Jurusan Budidaya Pertanian. Vol 4, No. 2

Rukmana, R. 1997. Usaha Tani Jagung. Kanisius. Yogyakarta.

Saleem A, HI Javed, Z Ali, I Ullah. 2003. Response of maize cultivars to different NP levels under irrigated condition in Peshawar valley. Pak. J. Bio. Sci. 6(14): 1229-1231.

Siswono, 2004. Jagung Manis Rendah Lemak dan Kolesterol. Gizi net

Subaedah, St., S. Numba dan Saida. 2018. Penampilan Pertumbuhan dan Hasil Beberapa Genotipe Calon Hibrida Umur Genjah di Lahan Kering. $J$. Agron. Indonesia. 46 (2):169-174

Surtinah, 2008. Waktu Panen yang Tepat Menentukan Kandungan Gula Biji Jagung Manis (Zea Mays saccharata). J. Ilmu Pertanian $4(2): 1-6$

Surtinah, 2012. Korelasi Antara Waktu Panen dan Kadar Gula Biji Jagung Manis (Zea mays saccharata Sturt). Jurnal Ilmiah Pertanian . 9(1): 1-6

Syukur, M dan A. Rifianto. 2014. Jagung Manis. Penebar Swadaya. Jakarta. 